\title{
Collective memory and means of claims in democracies: Evidence from Chile (2019-2021)
}

\author{
Armando N.G.L. Martins ${ }^{\mathrm{a}, *}$, Pedro Hemsley ${ }^{a, 1}$ \\ ${ }^{a}$ Institute of Economics / Federal University of Rio de Janeiro (IE-UFRJ). Avenida \\ Pasteur, 250, Palácio Universitário, Rio de Janeiro, Brazil
}

\begin{abstract}
There is a longstanding discussion among democracy theorists on the importance of voting and protests for the people to be heard. This article argues that protests are a primary driver of political engagement in nations with a memory of institutional violence. The hypothesis is tested in the case of Chilean protests from October 2019 to March 2020 triggered by police violence (Estallido Social) and the Constituent Plebiscite conducted in October 2020 in response to the protests. Political violence plagues the history of Chile, in particular in the authoritarian era of the Pinochet regime. Qualitative evidence indicates a strong reaction from the civil society against this trauma. Quantitative assessment is done through Weighed LS and 2SLS estimates for 289 municipalities. The evidence suggests that where there was more political victimization in the Pinochet era, there was more engagement in the Estallido Social. However, these localities also participated less in the plebiscite and the voting on constituent members and made no more significant effort to favor any party coalition.

Keywords: Constitutional Change, Protests, Institutional Violence, Collective Memory

JEL: D74, D72
\end{abstract}

\footnotetext{
* Corresponding author

Email address: armando.martins@ppge.ie.ufrj.br (Armando N.G.L. Martins)
} 


\title{
1. Introduction
}

\author{
Ay policía que vida elegiste vos / \\ verduguear a la gente es tu \\ vocación / matar a la gente pobre \\ es tu profesión / y así brindarle a \\ los ricos la protección / ya vas a \\ ver / las balas que vos tiraste van \\ a volver. \\ Chilean Protest song \\ Unknown composer, inspired by \\ Dany Lescano y su Flor de Piedra
}

Does collective memory in democracies condition if people make claims in the Streets or in the Voting Booth?

Universal suffrage mechanisms are the most distinctive feature of democratic societies. Elections are means to make politicians have vertical accountability towards the people. Nonetheless, the recognition of civil, political, and economic rights can evolve from an engaged society outside elections. The use of freedom of association and speech may articulate collective social organizations, leading to diagonal accountability. Thus, we have two types of accountability with different languages from the people to the power. (Lührmann et al., 2020)

In both ways, collective memory can be a notable variable that explains political engagement by integrating political emotions and institutional persistence theories. A general sentiment of unfair treatment by governments (Passarelli and Tabellini, 2017) and relative deprivation of realizing expected social goals (Gurr 2015) can drive social unrest. Nevertheless, these emotions can occur due to current policies and can interact with the persistence of past institutional features. Collective memory is a sociological concept formalized by Maurice Halbwachs. It consists of a body of information and values built among a social group on events to be remembered by their individuals. More than an autobiographi- 
memory, these past events are remembered directly by those who lived it or indirectly by documents, oral traditions, and ceremonies. In this case, collective memory becomes a social institution through generations (Halbwachs, 2020).

Even if institutional reforms occur, some institutions can remain into social exclusionary culture or policy (Robinson, 2000) and trigger social dissatisfaction. Collective memories can lead to support to democracy, but they also might backfire. On the one hand, elites can manipulate it to entrench their power (Belmonte and Rochlitz, 2020); on the other hand, memories can also fuel claims against elites outside democracy (Ticchi et al. 2013). In democratic contexts,

30 Çidam (2021) argues that protests can lead to social experimentation within the democratic process, leading to institutional robustness.

In this paper, we assessed the impacts of historical violence by the State on present political engagement. Chile has a suitable case to test these impacts (see section 2): between 1973 and 1989, the country faced a violent military regime

35 that victimized over 40,000 people; it passed through a democratization process in 1988 with the persistence of institutional features from the dictatorship, such as the police organization and the core of 1980 Constitution; its people engaged in one of the largest waves of protests in the Global South according to the Carnegie Endowment for International Peace (2021), which pressured the

40 right-wing president Sebastian Piñera and the Chilean national congress to the installment of a new constituent initiative.

口 After a detailed theory-building process tracing analysis (Beach and Peder$\operatorname{sen}(2016)$ ), we formulated hypotheses on how the memory of Pinochet victims can induce different forms of political engagement: protests or voting. We tested these hypotheses in cross-section regressions from 289 municipalities (comunas), contemplating the number of demonstrations, participation, and voting into the constituent plebiscite as dependent variables and the number of victims in the military regime in the primary independent variable. The regressions were estimated by least squares and two-stage least squares, both weighted by population. To tackle confounding issues of historical repression and political engagement by the same older electoral safe-seats, we followed Bautista et al. 
(2021) in using the placement of military bases before 1970 as an exogenous variable of political repression in the Pinochet Era (see the discussion in section three).

The estimates appoint that places with more victims in the Pinochet regime had more protests but less participation in the constituent plebiscite. No results were found for whom the population voted. Considering the hypotheses made in the case study, the results appoint that the memory of past institutional violence induces political mobilization by protests - especially against present repression. However, little can be said about engagement in the voting system. Related mechanisms for complementary evidence in autobiographical memory can be assessed by surveys of survivors (see Bautista (2016)).

In the next section, we present the Chilean case study that underlies our analysis.

\section{Case Study}

\subsection{Antecedents: the Pinochet regime repression}

In 1973, General Augusto Pinochet overthrew the civil government of Salvador Allende. The Allende government won the elections in 1969 as a coalition of left-wing parties (Unidad Popular), and its plan consisted of a path to

70 Marxian socialism. The implementation of strong price controls, redistributive policies lead to economic instabilities and political polarization (Dornbusch and Edwards, 1990). Once Pinochet rose in power, the military junta engaged in the first years into an anti-communist witch hunt against former politicians in the Allende government, trade unions, and dissidents in general. The big 75 part of repression was made in the first months by the armed forces and police officers (Carabineros). In 1974, repression went centralized by one single agency (Dirección de Inteligencia Nacional - DINA). Under external pressure against human rights violations, DINA were replaced by another agency, this one "more supervised", in 1977 (Central Nacional de Informaciones - CNI)

${ }_{80}$ (Policzer, 2009). Official records appoint that 3,216 people were killed or forcibly 
disappeared and 38,254 people were imprisoned for political reasons, and $94 \%$ of these prisoners were tortured during the dictatorship period (Bautista et al. 2021).

Pinochet and the Military concentrated political power, establishing a new constitution in 1980. This constitution extended Pinochet's mandate and privatized the public pension scheme in Chile, minimized interventions in the economy, and biased the electoral system towards right-wing parties (Bautista et al. 2021). The repression also fomented civil resistance, which was a source of concern by the Junta (Esberg, 2021). Along with the economic crises in the 80s, social organizations made strikes and protests in favor of democratization, which is also supported by international pressure. In 1988, the plebiscite for the continuation of Pinochet's government took place. The "No" gained with $55 \%$ of the votes and the coalition "Concertación" for the no won the elections in the next mandate and the following until 2005 (Bautista et al., 2021).

The Chilean democratization process happened under accusations of incompleteness. Pinochet remained the chief of armed forces until 1998 and had a lifetime seat in congress until 2002, the year he resigned due to judicial prosecution for corruption and human rights accusations (Bautista et al., 2021). Despite the several constitutional reforms for the electoral improvement, the core of the 1980 constitutional remained, which instigated debates on its undemocratic nature (Garretón, 1999).

\subsection{Estallido Social and the Chilean Constituent}

The trigger of the 2019-2020 social unrest in Chile was the readjustment of transport fare in Santiago. On October 1st, 2019, the Public Transport Expert Panel established the increase by 10 pesos the bus fare and 30 pesos the peak and off-peak metro fare. The price scheme were to be enforced on October 06th (Panel de Expertos del Transporte Público Ley Nº 20.378, 2019).

The first organized protests were done on October 7th. High-school students in downtown Santiago massively jumped the turnstile in metro stations for several days (Emol, 2019). A week later, the first 'violent' act happened: a student 
got arrested after the rupture of a glass door in Pedro de Valdivia Station (Vega, 2019).

A massive protest in several Metro stations had been organized on social media on October 18th (Rivera and Ruyt, 2019). However, October 16th was an inflection point into adhesion. In consult to Google Trends, the search for the term ' 18 de Octubre' reached its peak in Chile following the first clash with the Carabineros (Google, 2019). This clash occurred in the Santa Ana station, and the police arrested another four students (24Horas.cl, 2019). The metro suspended the activities in several stations in Line 5. In the afternoon, another group of students threw down the gate of Plaza de Armas station (Arias, 2019). On October 17th, the tension escalated even further, with depredation of San Joaquin station (CNN Chile, 2019b and arrest of 133 students Al Jazeera. 2019).

On October 18th, \#ChileDespertó (Chile woke up). The protests gained large scale, and protesters fully occupied downtown Santiago - this event also named Santiagazo. The Electricity company Enel's headquarters was damaged by fire - the electricity fare was also a complaint, but the accusation of arson was not still solved (Lara, 2019). Large-scale clashes with the Carabineros also happened: protesters received water jets and tear gases in many city points. ${ }_{130}$ At night, residents of Santiago organized a massive cacerolazo (pot-banging protest) at home supporting the demonstrations in the streets (Rollano, 2019). In response to the protests, the Minister of Defense Andrés Chadwick claimed in a press conference that they would use the National Security Act against the 'violentists'. Furthermore, the Metro company president announced that the Metro would remain closed for one week, with no mention in stepping back the readjustments (CNN Chile, 2019a). At the end of the night, the President of Chile Sebastián Piñera was seen in a luxury restaurant, sparking criticism in public opinion (MercoPress, 2019).

In the first minutes after midnight, President Piñera decreed state emer140 gency in Santiago and nearby cities, and the armed forces became allowed to impose order. The armed forces chief stipulated curfews into the area of state 
emergency. Despite these efforts, the protests remained in Santiago and rapidly spread to other country regions - for instance, protesters made barricades in the streets, and the police barracks were stoned in Concepción (Stuardo, 2019). Piñera extended the state emergency to almost all regional capitals in Chile. The imposition of a state emergency and the use of curfews outside natural disasters were the first ever since the end of Pinochet's regime (France 24, 2019). Sebastián Piñera declares that the country was "at war with a powerful and implacable enemy", which sparked further revolt (Prensa Presidencia, 2019d). However, he proposed to suspend the readjustment and a reunion of leaders of different powers to discuss solutions to the high costs of living and the 'safety of the family' (Prensa Presidencia, 2019b).

On October 20th, President Piñera had a reunion with the President of the Deputies Chamber Iván Flores, the President of the Supreme Court Haroldo 155 Brito, and the President of the Senate Jaime Quintana. In this reunion, Quintana proposed the resume of writing a new constitution (Leal, 2019). On the same day, an extraordinary session in the parliament suspended the Metro fare readjustment (Senado, 2019). Meanwhile, protests intensified, with pacific protesters supporting students - claiming "it was not for the 30 pesos (of readjustment) but 30 years (of democracy)" (Maciel, 2019). However, arsons, lootings, and violent clashes also escalated, with police shots, tear gas, and water jets - the first deaths were recorded. It was seen in this period also the formation of cabildos abiertos, open and decentralized assemblies that are self-composed to discuss social issues and solutions. Examples of themes were the new constitution, drug legalization, and local network for service provisions (Observatorio de Metodos Deliberativos, 2019). Finally, on October 21st, social leaders organized themselves to formalize the urge for a new constitution (Flores, 2019).

On October 22th, President Piñera presented a package of reforms named "New Social Agenda", which consisted of: increase of $20 \%$ in the pensions, creation of public insurance for medication and grave diseases, fare stabilization mechanism for electricity, tax increase for high incomes, wage reduction of high public workers and limitation of re-elections and the number of congress- 
men (Prensa Presidencia, 2019a). However, the measures were received as too modest, even to Piñera's allies (La Tercera, 2019).

Three days after, "La Marcha Más Grande De Todas" (the greatest march of all) took place (El Desconcierto, 2019)- with around 1,000,000-1,500,000 people in Santiago, 50,000 in Concepción and similar quantity in Valparaíso. On October 27th, 100,000 people pacifically marched between Viña Del Mar and Valparaíso but faced police repression (teleSUR, 2019). Both protests had additional claims for the impeachment of President Piñera and against private pension, high costs of living, and lack of public services. Under pressure, Sebastián Piñera decreed the end of state of emergency and the armed forces on the streets (Gobierno de Chile, 2019). Piñera also invited his ministries to renounce, which was accepted by eight ministries, including the ministry of public security (Deutsche Welle, 2019).

Even after the end of the state of emergency, the protests remained in smaller quantity, often made by organized social groups. On November 4 th, trade unions called for a general strike for a new constitution - on this day, 20,000 people participated, and the protest was marked by one of the most violent in the period (Europa Press, 2019). On the day after, the protests reached the oriental part of Santiago, the country's financial center. The right-wing party Unión Democratica Independiente headquarters and memorial of Jaime Guzmán, mentor of Pinochet's 1980 constitution, were vandalized (Ahumada and Vera, 2019). Due to the denounces of human rights violations, the Ministry of Public Security announced on November 9th that the government would reform the police (infobae, 2019).

On day November 7th, the Chilean Municipality Association approved a call for citizen consult for a New Constituent Asociación Chilena de Municipalidades, 2019). On November 12th, President Piñera announced three National 200 Agreements in response to the protests: for the peace, as he calls the retired military to reintegrate the security forces; for the justice, as he reiterates the Social Agenda, and for the new constitution (Prensa Presidencia, 2019c).

On November 15th, an agreement between government and opposition is 
made to make a constituent's plebiscite. A project of a constitutional amend-

According to the electoral service (https://www.servel.cl), almost 6.2 million people voted for the constitutional convention composition in May 15-16th. The coalition Vamos por Chile (right-wing) gained 37 seats, Lista del Apruebo 

independents gained 48 seats. The new constitution will be written and voted by the convention in 2022, and then a new popular plebiscite will take place to confirm the substitution of the old constitution.

\subsection{Hypotheses formulation}

Considering the Estallido social, hypotheses can be formulated to guide our analysis about the persistence of the memory on the Pinochet regime's victims into Chilean political engagement. Funk and Velasco $(2020)$ argue that Estallido Social happened because of institutional trust meltdown and hopelessness. However, even the authors acknowledge that initial conditions matter for this circumstantial crisis. Here, we can hypothesize that collective memory can have a special place in these conditions.

Our first hypothesis is on protests. As mentioned in the antecedents to Chilean democracy, the people in the country used strikes and protests during the Pinochet government to put pressure for democratization when the electoral where the iron fist of repression was more felt. As argued by Ticchi et al. (2013), collective memory can be a notable driver to resistance against authoritarianism. However, we can also argue that this memory against repression can persist even when democratization is achieved and drive protests, like the ones seen in Estallido Social.

Hypothesis 1: Memories on Pinochet regime's victims led to more political claims through protests.

A second hypothesis deals with a demand for electoral participation. Even at the end of Pinochet's regime, the democratic governments remained the core of the constitution written in 1980, with minor revisions made since then. This sparked criticism claiming its undemocratic nature. People affected by authoritarian repression might be more vocal in this criticism. The demand for a new constitution appeared in large protests, like the La Marcha más grande de todas. 
The acts of vandalism against the Jaime Guzmán memorial can be seen as a

tution became the main concession the Piñera government offered in response to the $2019-2020$ protests.

Hypothesis 2a: Memories on Pinochet regime's victims led to more voting participation.

Velasco (2021) argues that the rejection of neoliberal policies is unlikely to explain the Estallido Social: leaders of anti-liberal movements, such as the Communist Party, the Teacher's Union, and 'No + AFP' (anti-privatized pension movement) failed to get a seat in the convention. A notable characteristic of Chilean democracy is that the hybrid constitutional features inherited from eral social complaints are that parties are increasingly disconnected from civil society (Luna and Altman, 2011). Sensitivity against flawed participation might also be higher where participation was more violently suppressed in the past. Velasco argues that the root of the Chilean constitutional revolution was the

\section{Quantitative Data and Methodology}

This section describes the specification, data, and methodology of the estimations used to test the hypotheses discussed in subsection 2.2 .

The econometric specification is inspired by Bautista et al. (2021) on the effects of Pinochet repression on the plebiscite of 1988 that voted for the end of 


$$
\text { poli }=f(\text { repre, } \text { Controls, FE), }
$$

, where poli is the political mobilization variable on protests and constituent plebiscite, repre is the variable on the political repression from Pinochet era, the presence of controls related to demography, geography, and politics pre-Pinochet and FE is the state (Región) level dummies.

Considering the hypothesis $1,2 \mathrm{a}$, and $2 \mathrm{~b}$, our general initial hypothesis is that of dictatorship memory and institutional persistence: localities that were more affected by the Military regime repression protested more in the "Estallido Social". In addition, they engaged more to vote for a new Constitution to replace the last one designed by the Pinochet government.

To test quantitative hypotheses in this paper, a database on 289 municipalities (Comunas) was constructed (See Appendix A for the detailed data description and sources). The methodology is also inspired by Bautista et al. (2021). The least-squares are used to evaluate the conditional mean between the protests or plebiscite results and the Pinochet repression. However, The authors argue that weighting the estimates for the population is strategic for analyzing socio-political action because it gives more focus and equal treatment on individual behavior, irrespective of the municipality size.

Moreover, such estimates can also suffer from cofounding issues. For example, it is possible to argue that the localities where there were more victims of Pinochet, more protests in 2019/2020, and more voting for the constituent were the same due to even older historic vote orientation for the left-wing agendas. Bautista et al. (2021) treat such issue by using the presence of military bases past 1970, there is, before the Pinochet coup in 1973, as an instrument for victimization.

The authors argue that the establishment of military bases was not correlated with the city inhabitants' right-wing or left-wing orientation - the government in both directions almost equally contributed to the construction of these bases. Even so, Pinochet used the military bases as centers of detention and torture 
of dissidents in his regime. Thus, they are highly correlated with victimization.

320 Bautista et al. (2021) also argue that, when controlled by the 1970 election results, the use of military presence renders fixed the influence of the political orientation of a locality pre-Pinochet and gives a net effect of victimization into contemporary variables of political attitudes.

\section{Econometric results}

325 In this section, we can assess the effects on the social mobilization influenced by the local memory of political victimization in the Pinochet era. As it can be seen in the following tables, all LS regressions have good fit of adjustment $(R>.65)$ and accepts global significance $(\operatorname{Prob}(F)<.10)$. The IV also rejects the hypothesis of weak instrument $(F>10)$.

\subsection{Protests and Constituent Plebiscite Turnout}

In Table 1, one can infer that localities where more victimization was made had more protests along the Estallido Social. The same result is seen where the Pinochet regime victimized more residents. The estimates show what is expected: the memory of Pinochet's victims made the residents more sensitive to State repression and organized more protests.

Taking into account the IV estimates as the more robust in the table, one can infer that the incidence of 1 victim per 10,000 inhabitants in a locality during the Pinochet era corresponds on average to almost 0.4 protests per 10,000 inhabitants during the "Estallido Social", nearly 30 years after. Moreover, following the memory of past neighbors, the rates are even higher to localities whose residents were more victims by the military regime repression: 1 victim per 10,000 inhabitants in a locality during the Pinochet era corresponds to 0.55 protests per 10,000 inhabitants during the 2019-2020 protests.

However, one can see that where there were more Pinochet victimization or victim residents, the voters had less participation in voting for the constituent plebiscite. Table 2 presents this result. Where the victimization during 
the Pinochet era hit one people per 10,000 inhabitants, the municipality faced on average a reduction of almost $2 \%$ in the rate of participation in the 2020 plebiscite. The estimates are even more sensitive for localities of higher victim residents: the repression of 10 residents per 10,000 inhabitants in a given city represented a reduction of $2.8 \%$ into the voting.

\subsection{Constituent approval}

Now we can turn to the effects of past political victimization in the constituent approval. Table 3 presents the regression results considering the percentage of constituent approval (the first four columns) and the percentage of full popular convention, given the constituent approval (the last four columns). As we can see, almost no evidence that places that suffered more victimization or resident victims of the Chilean military regime voted more for the constituent or the most "radical" assembly composition. 
Table 1

LS and IV Estimates: Protests/10k Inhabs

\begin{tabular}{ccccc}
\hline \multicolumn{5}{c}{ Protests } \\
& LS & IV & LS & IV \\
\hline Victims/10k Inhabs & $\mathbf{0 . 0 9 1 * * *}$ & $\mathbf{0 . 3 9 0 * * *}$ & \\
& $(0.032)$ & $(0.144)$ & \\
& {$[2.856]$} & {$[2.708]$} & & \\
Victim Residents/10k Inhabs & & & $\mathbf{0 . 0 8 9 *}$ & $\mathbf{0 . 5 5 0 * * *}$ \\
& & & $(0.048)$ & $(0.189)$ \\
& & & {$[1.835]$} & {$[2.917]$} \\
\hline LS Adjusted R ${ }^{2}$ & 0.710 & & 0.706 & \\
LS F-statistic & 33.101 & & 32.390 & \\
p-value (LS F-statistic) & 0.000 & & 0.000 & \\
IV F-statistic & & 65.147 & & 40.451 \\
State Dummies & $\mathrm{x}$ & $\mathrm{x}$ & $\mathrm{x}$ & $\mathrm{x}$ \\
Controls & $\mathrm{x}$ & $\mathrm{x}$ & $\mathrm{x}$ & $\mathrm{x}$ \\
N. Obs. & 289 & 289 & 289 & 289 \\
\hline
\end{tabular}

Notes: Marginal significance levels: $(* * *)$ denotes $0.01,(* *)$ denotes 0.05 , and $\left(^{*}\right)$ denotes 0.10 . All regressions have control for distance to Santiago and regional capital, 2017 population and rural share, and vote shares for Allende and Alessandri in 1970. Weights: 2017 population. Coefficient in bold, Newey-West standard errors in parentheses, and Tstatistic in brackets. IV F-statistic is the Cragg-Donald weak instrument test. 
Table 2

LS and IV Estimates: Turnout (Approval of Constituent)

\begin{tabular}{ccccc}
\hline & \multicolumn{4}{c}{ Turnout (Approval of Constituent) } \\
& LS & IV & LS & IV \\
\hline Victims/10k Inhabs & $\mathbf{- 0 . 6 3 2 * * *}$ & $\mathbf{- 1 . 9 8 0 * * *}$ & & \\
& $(0.236)$ & $(0.387)$ & & \\
& {$[-2.680]$} & {$[-5.110]$} & & \\
Victim Residents/10k Inhabs & & & $\mathbf{- 0 . 6 7 5 * *}$ & $\mathbf{- 2 . 7 9 0 * * *}$ \\
& & & $(0.324)$ & $(0.671)$ \\
& & & {$[-2.084]$} & {$[-4.161]$} \\
\hline LS Adjusted R ${ }^{2}$ & 0.755 & & 0.748 & \\
LS F-statistic & 41.325 & & 39.755 & \\
p-value (LS F-statistic) & 0.000 & & 0.000 & \\
IV F-statistic & & 65.147 & & 40.451 \\
State Dummies & $\mathrm{x}$ & $\mathrm{x}$ & $\mathrm{x}$ & $\mathrm{x}$ \\
Controls & $\mathrm{x}$ & $\mathrm{x}$ & $\mathrm{x}$ & $\mathrm{x}$ \\
N. Obs. & 289 & 289 & 289 & 289 \\
\hline
\end{tabular}

Notes: Marginal significance levels: $\left({ }^{* *}\right)$ denotes $0.01,(* *)$ denotes 0.05 , and $\left(^{*}\right)$ denotes 0.10 . All regressions have control for distance to Santiago and regional capital, 2017 population and rural share, and vote shares for Allende and Alessandri in 1970. Weights: 2017 population. Coefficient in bold, Newey-West standard errors in parentheses, and Tstatistic in brackets. IV F-statistic is the Cragg-Donald weak instrument test. 


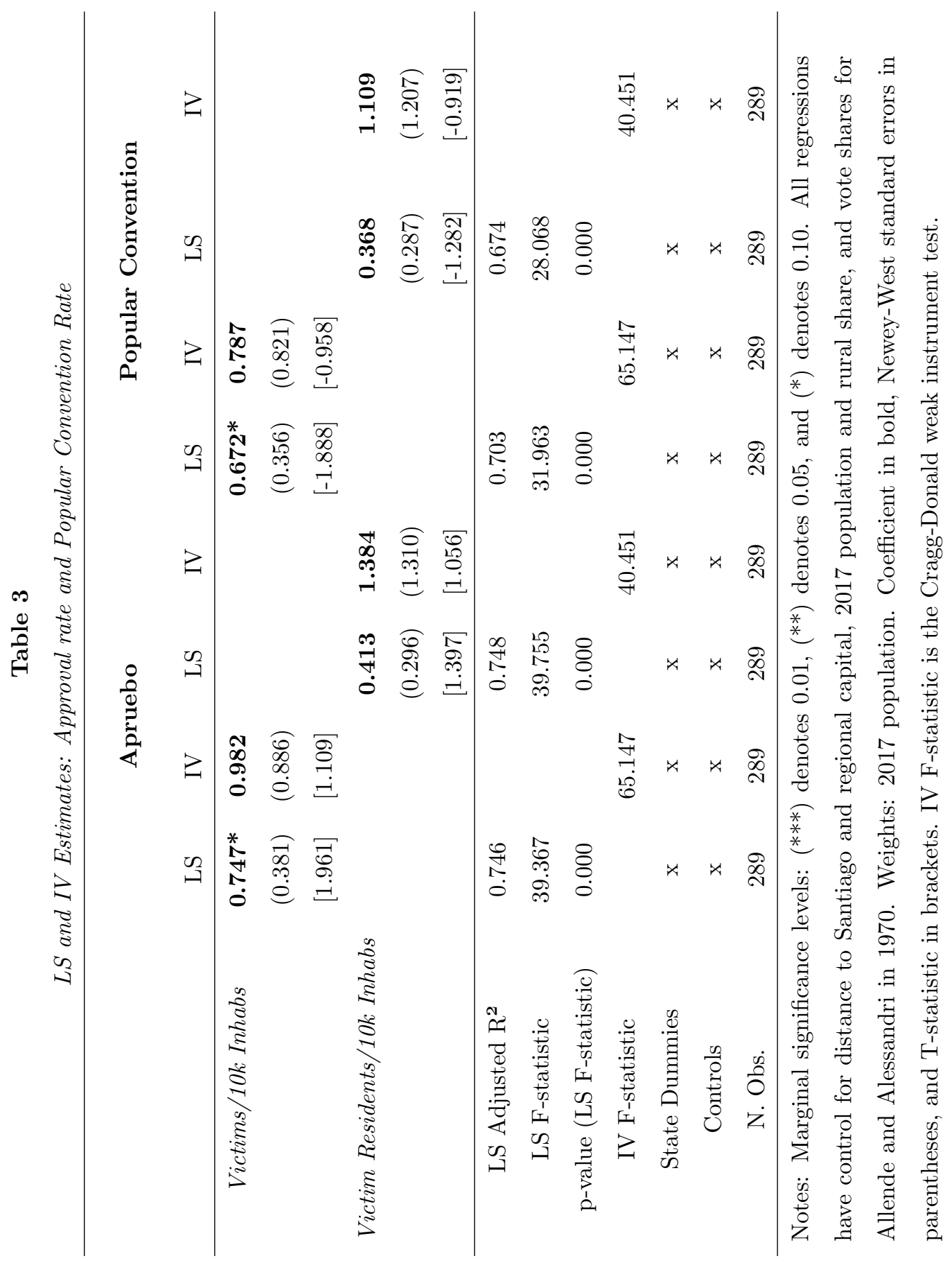


from $48 \%$ in 2003 to $68 \%$ in 2013 . However, $41 \%$ of the people interviewed in 2013 attributed the responsibility of the coup of 1973 to Pinochet himself, 6\% to the military, and only $2 \%$ to the Right (comparing with $34 \%$ to Pinochet, 
$7 \%$ to the military, and $4 \%$ to the Right in 2003). These results indicate an regime to present political actors and institutions by the public opinion.

Since the municipalities with more victims made more protests, what was the factor that influenced people affected by Pinochet's repression to go to the streets, other than more political participation, more public services, or punish

increasing detachment of most of the actors and institutions in the military the incumbent party? The backfire of police repression of unarmed protests is discussed by literature but emphasizes the role of communication infrastructure in the protest scalability (see Sutton et al. (2014)). Here, we can infer that past institutional violence memory can be a driver.

There was a late, small but existent effort to convict ex-army chiefs and reform the armed forces to rule out the reminiscences of Pinochet's organization (Dreisbach, 2015), little was done to the police. Despite the pressure to reform the Carabineros due to the human rights violations during the 2019 protests, the initiatives remained paralyzed (Torres, 2021).

State violence was present in almost all the Estallido Social incidents; the mobilization scales up when the first clashes between students and Carabineros occurred; it spread all over the country following the imposition of the emergency state and begin to scale down when the president revoked this decree.

Summing up, the cultural aspect that would persist to the "Estallido Social" would be the revolt against State violence itself, following the police confront against early protesters that were against subway tariff adjustment in Santiago. Sensitivity to State violence drives people affected by past victims' memories to go to protests (hypothesis 1). However, it does not motivate people not to go to the Voting Booth to claim more accountability by more participatory institutions or punish eventual unresponsive incumbent parties (hypotheses $2 \mathrm{a}$ and $2 \mathrm{~b})$. 
Table 4

OLS and IV Estimates: Turnout (Composition of Convention)

\begin{tabular}{ccccc}
\hline & \multicolumn{4}{c}{ Turnout (Composition of Convention) } \\
& OLS & IV & OLS & IV \\
\hline Victims/10k Inhabs & $\mathbf{- 1 . 0 4 6 ^ { * * * }}$ & $\mathbf{- 3 . 2 1 2 * * *}$ & & \\
& $(0.275)$ & $(0.490)$ & & \\
& {$[-3.800]$} & {$[-6.552]$} & & \\
Victim Residents/10k Inhabs & & & $\mathbf{- 1 . 1 6 0 * * *}$ & $\mathbf{- 4 . 5 2 6 * * *}$ \\
& & & $(0.428)$ & $(0.856)$ \\
& & & {$[-2.711]$} & {$[-5.287]$} \\
\hline OLS Adjusted R ${ }^{2}$ & 0.589 & & 0.578 & \\
OLS F-statistic & 19.727 & & 18.922 & \\
p-value (OLS F-statistic) & 0.000 & & 0.000 & \\
IV F-statistic & & 65.147 & & 40.451 \\
State Dummies & $\mathrm{x}$ & $\mathrm{x}$ & $\mathrm{x}$ & $\mathrm{x}$ \\
Controls & $\mathrm{x}$ & $\mathrm{x}$ & $\mathrm{x}$ & $\mathrm{x}$ \\
N. Obs. & 289 & 289 & 289 & 289 \\
\hline
\end{tabular}

Notes: Marginal significance levels: $(* * *)$ denotes $0.01,(* *)$ denotes 0.05 , and $(*)$ denotes 0.10 . All regressions have control for distance to Santiago and regional capital, 2017 population and rural share, and vote shares for Allende and Alessandri in 1970. Weights: 2017 population. Coefficient in bold, Newey-West standard errors in parentheses, and Tstatistic in brackets. IV F-statistic is the Cragg-Donald weak instrument test. 
Table 5

OLS and IV Estimates: Percentage of Voters (Vamos por Chile)

\begin{tabular}{ccccc}
\hline & \multicolumn{4}{c}{ Percentage (Vamos por Chile) } \\
& OLS & IV & OLS & IV \\
\hline Victims/10k Inhabs & $\mathbf{- 0 . 7 3 3 ^ { * * }}$ & $\mathbf{- 0 . 6 5 3}$ & & \\
& $(0.341)$ & $(0.834)$ & & \\
& {$[2.152]$} & {$[-0.782]$} & & \\
Victim Residents/10k Inhabs & & & $\mathbf{- 0 . 4 3 5}$ & $\mathbf{- 0 . 9 2 0}$ \\
& & & $(0.273)$ & $(1.221)$ \\
& & & {$[-1.589]$} & {$[-0.753]$} \\
\hline OLS Adjusted R & & & 0.700 & \\
OLS F-statistic & 36.046 & & 31.495 & \\
p-value (OLS F-statistic) & 0.000 & & 0.000 & \\
IV F-statistic & & 65.147 & & 40.451 \\
State Dummies & $\mathrm{x}$ & $\mathrm{x}$ & $\mathrm{x}$ & $\mathrm{x}$ \\
Controls & $\mathrm{x}$ & $\mathrm{x}$ & $\mathrm{x}$ & $\mathrm{x}$ \\
N. Obs. & 289 & 289 & 289 & 289 \\
\hline
\end{tabular}

Notes: Marginal significance levels: $(* * *)$ denotes $0.01,\left({ }^{* *}\right)$ denotes 0.05 , and $\left(^{*}\right)$ denotes 0.10 . All regressions have control for distance to Santiago and regional capital, 2017 population and rural share, and vote shares for Allende and Alessandri in 1970. Weights: 2017 population. Coefficient in bold, Newey-West standard errors in parentheses, and Tstatistic in brackets. IV F-statistic is the Cragg-Donald weak instrument test. 
Table 6

OLS and IV Estimates: Percentage of Voters (Lista del Apruebo)

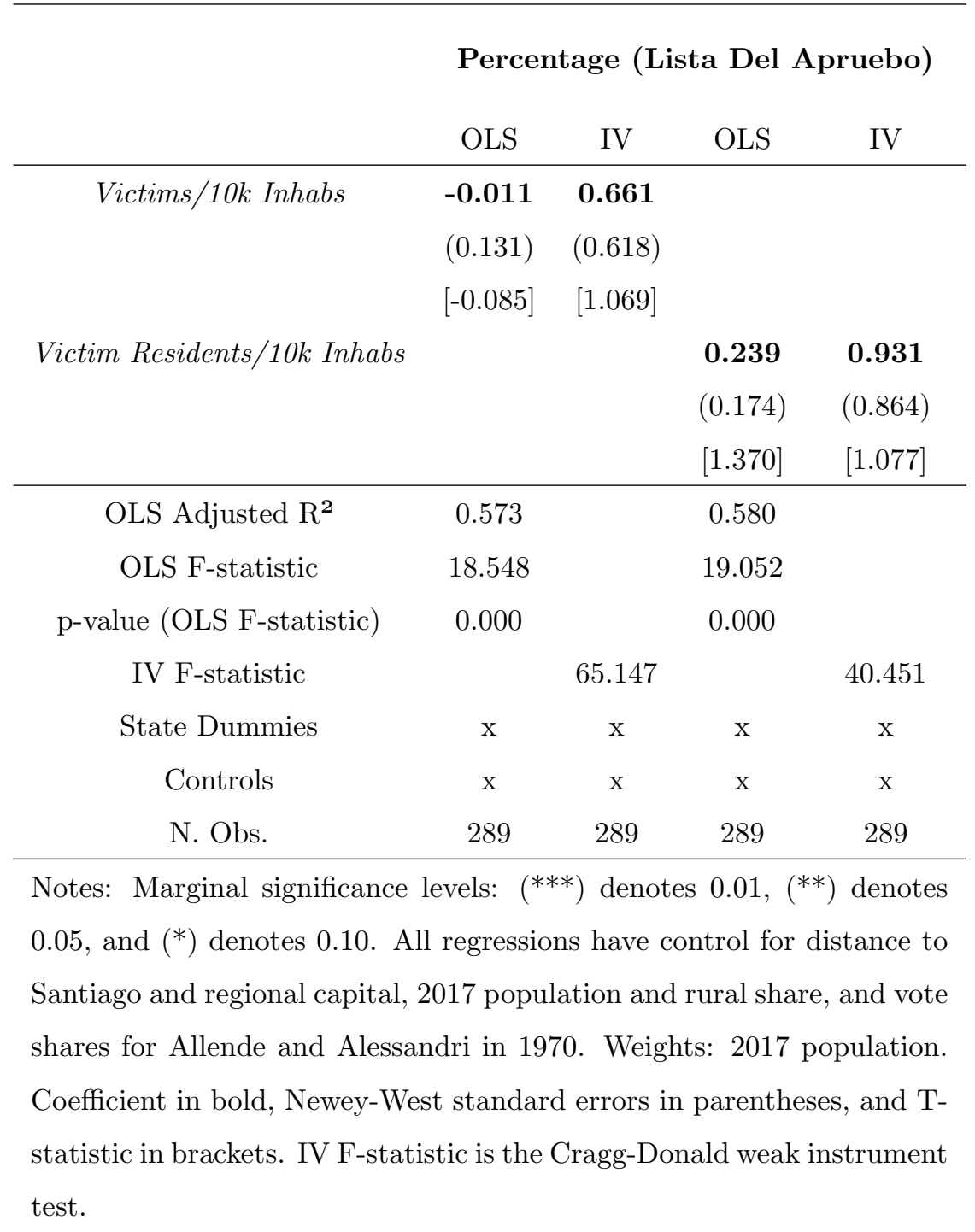




\section{Conclusion}

In this work, we investigate the persistence of collective memory on past institutional violence into present political engagement in democracies. The case of Chile gives us a representative event where the legacy of a military regime was often appointed as a latent driver of street protests that led to a plebiscite for a constitutional change.

The results appoint that the localities more affected by the military repression in the Pinochet era indeed had more protests in the Estallido Social. However, it also participated less in the plebiscite, less in choosing the constituent members, and did not punish the incumbent coalition or favored the opposition.

In the case of Chile, other factors could drive the specific pressure for a new constitution, such as Passarelli and Tabellini (2017) and (Gurr, 2015) general emotions of broken expectations and institutional mistrust, as theorized by Funk and Velasco (2020). However, for the scope of the collective memory of victims of Pinochet, our evidence suggests that this Chilean cultural legacy leads to the more affected people making their claims by protests in the streets instead of voting in the booth.

This evidence appoints that violent management of armed forces is one of the most sensitive topics for collective memory and public opinion in democratic societies. A significant implication is that proper institutional reform combined with an investigation of human rights violations of authoritarian regimes are fundamental to social peace in democratizing countries (Jelin, 2007).

\section{Acknowledgements}

The authors would like to thank Prof. Luis Martínez for kindly sharing his database on Pinochet repression and Jamil Civitarese for valuable suggestions that improved this work. 


\section{References}

24Horas.cl (2019). Nuevos disturbios se producen en Metro Santa Ana por llamados a evadir el pasaje. 24Horas.cl. Section: Nacional.

Ahumada, M. J. and Vera, A. (2019). Tras ataque a sede de la UDI y memorial de Jaime Guzmán senadores acusan "acto de violencia política". La Tercera.

Al Jazeera (2019). Chile protests: State of emergency declared in Santiago. Al Jazeera.

Amnesty International (2020). Eyes on Chile. Technical report, Amnesty International.

Arias, D. (2019). Evasión masiva en Metro Plaza de Armas: pasajeros botaron la reja de acceso y difundieron el caótico registro. Publimetro.

Asociación Chilena de Municipalidades (2019). Declaración Oficial AChM. 7 de noviembre 2019.

Bautista, M. (2016). Political Effects of State-led Repression: The Chilean Case. The Pearson Institute Discussion Paper Discussion Paper No. 27, The Pearson Institute.

Bautista, M. A., González, F., Martinez, L. R., Munoz, P., and Prem, M. (2021). The geography of repression and opposition to autocracy. American Journal of Political Science.

Beach, D. and Pedersen, R. B. (2016). Causal case study methods: Foundations and guidelines for comparing, matching, and tracing. University of Michigan Press.

Belmonte, A. and Rochlitz, M. (2020). Collective memories, propaganda and authoritarian political support. Economic Systems, 44(3):100771.

Carnegie Endowment for International Peace (2021). Global Protest Tracker. Technical report, Carnegie Endowment for International Peace, Washington, DC. 
Carreras, J. E. (2020). Bochornosa primera jornada de Festival: ataques, destrozos, saqueos y suspensión de las competencias. BioBioChile. Section: resumen-de-noticias.

CERC (2013). Barometro CERC: A cuarenta años del golpe militar. Technical report, CERC, Santiago.

CNN Chile (2019a). Gobierno invoca Ley de Seguridad del Estado y hace llamado a los chilenos a "unirnos contra la violencia". CNN Chile.

CNN Chile (2019b). Muletazos, validadores destruidos y carabineros retrocediendo: 3 registros que marcaron la jornada de evasión masiva. CNN Chile.

Cooperativa.cl (2019). Más de 3,7 millones de personas han asistido a manifestaciones durante la crisis, según Carabineros. Cooperativa.cl.

Cooperativa.cl (2020). Un muerto, ataques a cuarteles, saqueos y transporte suspendido dejó violenta jornada de protestas. Cooperativa.cl.

Cámara de Diputados de Chile (2019). Comisión de Constitución despachó reforma que habilita proceso constituyente.

Deutsche Welle (2019). Chile: Piñera cambia a ocho ministros, incluidos Interior y Hacienda. Deutsche Welle.

Dornbusch, R. and Edwards, S. (1990). Macroeconomic populism. Journal of Development Economics, 32(2):247-277.

Dreisbach, T. (2015). Civilians at the Helm: Chile Transforms Its Ministry of National Defense, 2010-2014. page 17.

El Desconcierto (2019). Los históricos registros que dejó La Marcha Más Grande de Chile. El Desconcierto.

Emol (2019). La cronología de los hechos que detonaron la crisis social y los días de estado de emergencia en el país. Emol. Section: Nacional. 
Esberg, J. (2021). Anticipating Dissent: The Repression of Politicians in Pinochet's Chile. The Journal of Politics, 83(2):689-705.

Europa Press (2019). Disturbios e incidentes violentos marcaron el "Súper Lunes" de protestas en Santiago. AmericaEconomia.

Flores, J. (2019). Líderes sociales exigen Asamblea Constituyente y seis medidas anti abusos de corto plazo. BioBioChile. Section: chile.

France 24 (2019). Chile vivió segundo día en toque de queda tras nueva jornada de protestas. France 24. Section: america-latina.

Funk, R. and Velasco, A. (2020). Institutional fragility, breakdown of trust: a model of social unrest in Chile. Technical Report DP15343, CEPR.

Garretón, M. A. (1999). Chile 1997-1998: the revenge of incomplete democratization. International Affairs, 75(2):259-267.

Gobierno de Chile (2019). Se Levanta El Estado De Emergencia En Todas Las Comunas Y Regiones Del País. Gobierno de Chile.

Google (2019). Google trends. URL=https://trends.google.es/trends/explore?date=201910-06\%202019-10-17amp;geo=CLamp;q=18\%20de\%20octubre.

Gurr, T. R. (2015). Why men rebel. Routledge.

Halbwachs, M. (2020). On collective memory. University of Chicago Press.

infobae (2019). El Gobierno de Chile anunció una reforma de Carabineros tras los cuestionamientos de los defensores de los DDHH. infobae.

Jelin, E. (2007). Public Memorialization in Perspective: Truth, Justice and Memory of Past Repression in the Southern Cone of South America. International Journal of Transitional Justice, 1(1):138-156.

La Tercera (2019). Diputada Sabat (RN): "La agenda que ha presentado el presidente es insuficiente, en eso estamos todos de acuerdo". La Tercera. Section: Política. 
Lara, E. (2019). Incendio descomunal afecta edificio de ENEL en centro de Santiago: evacuaron a 40 trabajadores. BioBioChile. Section: regionmetropolitana.

Leal, J. Q. (2019). Declaraciones del Presidente del Senado tras reunión de los tres poderes del Estado en La Moneda - Senado - República de Chile.

Luna, J. P. and Altman, D. (2011). Uprooted but Stable: Chilean Parties and the Concept of Party System Institutionalization. Latin American Politics and Society, 53(2):1-28. Publisher: Cambridge University Press.

Lührmann, A., Marquardt, K. L., and Mechkova, V. (2020). Constraining Governments: New Indices of Vertical, Horizontal, and Diagonal Accountability. 530 American Political Science Review, 114(3):811-820.

Maciel, A. (2019). 'No son los 30 pesos, sino los 30 años de indiferencia', dicen los manifestantes chilenos. Los Angeles Times en Español. Section: Internacional.

MercoPress (2019). Santiago on fire and with no transport and Piñera in a family party at a pizza parlor. MercoPress.

Ministerio Secretaría General De La Presidencia (2019). Ley 21200.

Observatorio de Metodos Deliberativos (2019). Análisis metodológico de cabildos y asambleas ciudadanas desarrolladas a partir del estallido social de octubre 2019. Technical report, Universidad Alberto Hurtado.

Panel de Expertos del Transporte Público Ley Nº 20.378 (2019). Resolución N $540 \quad$ 2. Technical report, Panel de Expertos del Transporte Público Ley N 20.378.

Passarelli, F. and Tabellini, G. (2017). Emotions and political unrest. Journal of Political Economy, 125(3):903-946.

Policzer, P. (2009). Rise and Fall of Repression in Chile. University of Notre Dame Press, 1 edition. 
Prensa Presidencia (2019a). Presidente Piñera anuncia Agenda Social con mayores pensiones, aumento del ingreso mínimo, freno al costo de la electricidad, beneficios en salud, nuevos impuestos para altas rentas y defensoría para víctimas de delitos.

Prensa Presidencia (2019b). Presidente Piñera anuncia suspensión del alza de pasajes en el transporte público y convoca a una mesa de diálogo para escuchar las demandas de la ciudadanía.

Prensa Presidencia (2019c). Presidente Piñera convoca a todo el país a un Acuerdo por la Paz y a condenar la violencia de forma categórica.

Prensa Presidencia (2019d). Presidente Piñera: "Estoy seguro de que, con la unidad de todos los chilenos, vamos a derrotar a los violentistas y vamos a recuperar el país en paz y el país con libertad que todos queremos".

Raleigh, C., Linke, A., Hegre, H., and Karlsen, J. (2010). Introducing acled: an armed conflict location and event dataset: special data feature. Journal of peace research, 47(5):651-660.

Rivera, V. and Ruyt, F. D. (2019). Evasiones masivas en Metro superan las 50 y policía dispone uso de Fuerzas Especiales. La Tercera. Section: Nacional.

Robinson, M. (2000). The construction and reinforcement of myths of race and crime. Journal of Contemporary Criminal Justice, 16(2):133-156.

Rollano, M. (2019). Masivos cacerolazos se toman Santiago en apoyo a protesta por alza del pasaje Diario y Radio U Chile. Diario UChile.

Senado (2019). Congelamiento del alza del transporte público a Ley.

Senado de Chile (2019). Luz verde a reforma habilitante del proceso constituyente.

Stuardo, M. (2019). Concepción se convierte en "campo de batalla" tras Estado 570 de Emergencia en el Gran Santiago. BioBioChile. Section: region-del-bio-bio. 
Sutton, J., Butcher, C. R., and Svensson, I. (2014). Explaining political jiu-jitsu: Institution-building and the outcomes of regime violence against unarmed protests. Journal of Peace Research, 51(5):559-573.

teleSUR (2019). Miles de chilenos marchan hacia el Congreso de Valparaíso. teleSUR.

Ticchi, D., Verdier, T., and Vindigni, A. (2013). Democracy, Dictatorship and the Cultural Transmission of Political Values. SSRN Scholarly Paper ID 2283556, Social Science Research Network, Rochester, NY.

Torres, C. (2021). Chile: aumentan las demandas para reformar Carabineros tras la muerte de un malabarista a manos de las fuerzas de seguridad. infobae.

Ulloa, C. (2020). Protestas en Chile: 580 detenidos y un muerto. CNN.

Urrejola, J. (2020). El boicot que quiere reformar el sistema educacional en Chile. Deutsche Welle.

Vega, M. (2019). Grupo de 300 estudiantes invaden estación Pedro de Valdivia del Metro: protestan por alza de pasajes. BioBioChile. Section: regionmetropolitana.

Velasco, A. (2021). Chile's Constitutional Revolution. Project Syndicate. Section: Politics \& World Affairs.

Çidam, (2021). In the Street: Democratic Action, Theatricality, and Political Friendship. Oxford University Press, 1 edition.

\section{Appendix A. List of Variables and Sources}

To test quantitative hypotheses in this paper, a database on 289 municipalities (Comunas) was constructed with the following variables:

1. Dependent Variables 
(a) Protests: number of protests in Chile between October 18th, 2019 and March 15th 202 ${ }^{1}$ per 10,000 inhabitants. The number of protests was obtained at ACLED database (Raleigh et al., 2010), and the number of inhabitants was obtained at the 2017 Chilean Census;

(b) Approval Turnout: rate of participation of the new constituent plebiscite, obtained at the Servicio Electoral de Chile (https://www.servel.cl);

(c) Apruebo: rate of approval of the constituent plebiscite, obtained at the Servicio Electoral de Chile (https://www.servel.cl);

(d) Popular convention: rate of voting for the full popular convention as the composition of the constituent (given Apruebo), obtained at the Servicio Electoral de Chile (https://www.servel.cl);

(e) Constituent composition Turnout: rate of participation of elections of the constituent members, obtained at the Servicio Electoral de Chile (https://www.servel.cl);

(f) Vamos por Chile: Percentage of voting for candidates of Piñera aligned right-Wing coalition Vamos por Chile, obtained at the Servicio Electoral de Chile (https://www.servel.cl);

(g) Lista del Apruebo: Percentage of voting for candidates of opposition center-left coalition Lista del Apruebo, obtained at the Servicio Electoral de Chile (https://www.servel.cl)

(h) Apruebo Dignidad: Percentage of voting for candidates of opposition left coalition Apruebo Dignidad, obtained at the Servicio Electoral de Chile (https://www.servel.cl)

2. Main Independent Variables

(a) Victims/10k Inhabs: number (by 10,000 inhabitants) of victimizations placed by the Pinochet regime in a municipality, condensed by Bautista et al. (2021);

\footnotetext{
${ }^{1}$ Period between the Santiagazo and the declaration of emergency state for the COVID-19 pandemic.
} 
(b) Victims Residents/10k Inhabs: number (by 10,000 inhabitants) of residents victimized by Pinochet Regime in a municipality, condensed by Bautista et al. (2021);

3. Controls

(a) Dist-RegCap: distance to regional capital, condensed by Bautista et al. (2021);

(b) Dist-Stgo: distance to Santiago, condensed by Bautista et al. (2021);

(c) Pop: population, obtained at the Chilean census 2017;

(d) Rural: Rural share, obtained at the Chilean census 2017;

(e) Share-Allende-1970: the share of votes for Salvador Allende (winner) in 1970, condensed by Bautista et al. (2021)

(f) Share-Alessandri-1970 the share of votes for Jorge Alessandri (the second place) in 1970, condensed by Bautista et al. (2021)

4. Instrument Variables

(a) DMilitaryPresence: dummy of military presence before 1970, condensed by Bautista et al. (2021). 